\title{
Phonological Variation of Pasar Kliwon Arabic Dialect Surakarta
}

\author{
${ }^{1}$ Arief Nur Rahman Al Aziiz; ${ }^{2}$ Muhammad Ridwan \\ 1,2Arabic Literature Department of Literature and Art Faculty, Universitas Sebelas Maret, Surakarta, Indonesia \\ Email: 1abu.musa90@yahoo.co.id
}

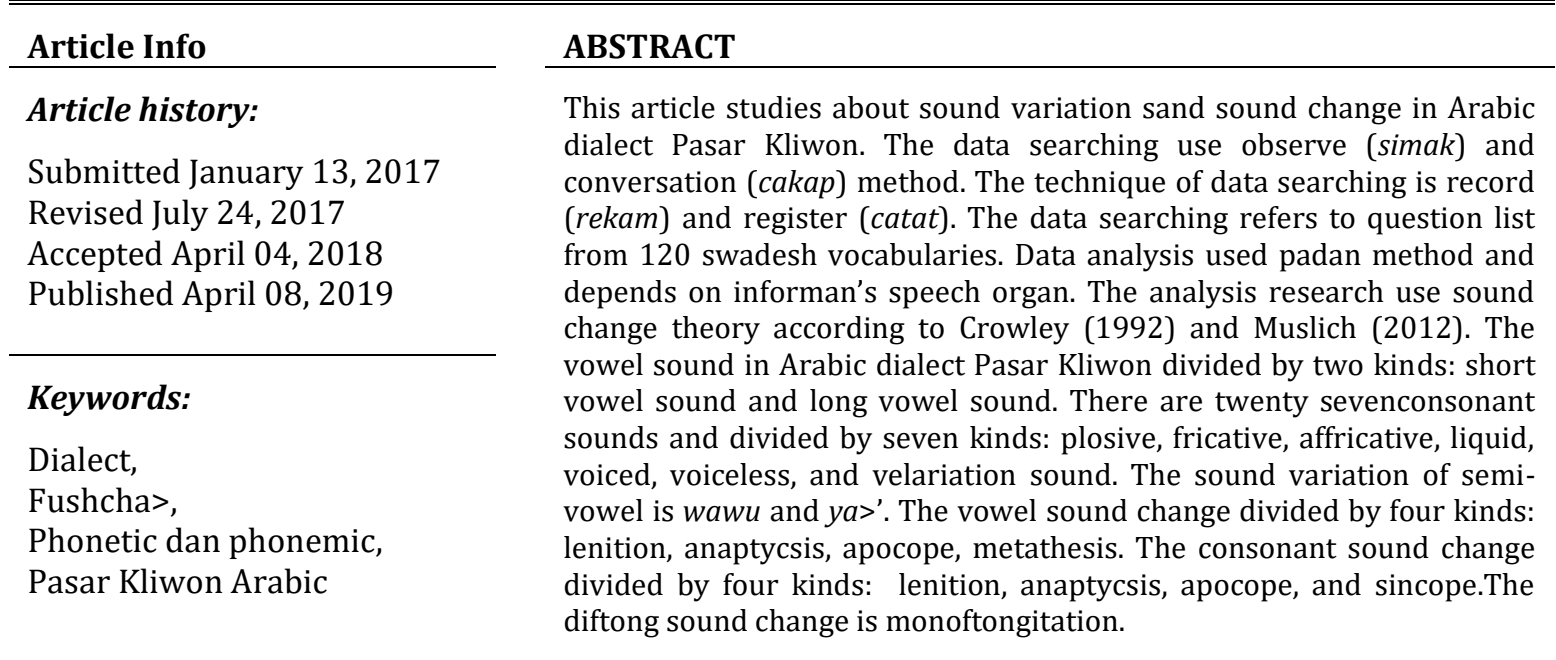

\section{Corresponding Author:}

Arief Nur Rahman Al Aziiz,

Universitas Sebelas Maret, Surakarta, Indonesia

Jl. Ir. Sutami 36 A, Kentingan, Surakarta, Indonesia.

Email: abu.musa90@yahoo.co.id

\section{INTRODUCTION}

Wafi (2004:79) divided Arabic dialect into two kinds, ba>'idah and ba>qiyah Arabic. The Arabic communities who live in the north of Hijaz talk with ba>'idah Arabic. This language appears before Islam and its addressing not arrive to us except some of inscription in previous places. Therefore, this language is said be "inscription Arabic." On the other, Arabic ba>qiyah is used by community of the Hijaz, Nejd, Yaman, Palestine, Ordo, Suria, Lebanon, Irak, Kuwait, Mesir, Sudan, and Maroko. Ya'kub (1982:117) divided ba>qiyah Arabic into two kinds, fushcha> and lahjah. Al-Khuli (1982:267) explained that fushchas is becomed centre of language study and literature from the other dialect and it is the most correct language all of dialects. Anis (1974:17) explained that dialect is collection from language characteristic which grew in certain area and its community used that language characteristic.

The dialect appeared as certain reason. Wafi (1974:105) mentioned one of reason is the spreading of Arabic around many non Arabic distriscts in Middle East. Arabic has changed ancient Yemen language and also Aram Dialect in the most of Irak and Persia. Therefore, Arabic in Persia was influenced by Aram Dialect. Biadsy, ett all (tt:3) in their scientific journal "Spoken Arabic Dialect Using Phonotatic Modelling" stated that nowadays Arabic Dialect is devided by 5. The First is called Gulf Arabic Dialect or GLF which is included Kuwait, Oman, Arab Saudi, Bahrain and Qatar. The Second Dialect is 
Iraqi Arabic or IRQ which is included Iraq Dialects. The Third is Levantine Arabic or LEV which is included Lebanon, Syria, Palestine, Israel and Jordan Dialects. Fourth is Egyptian Arabic or EGY included Egypt and Sudan Dialects. And the last is called Magrebi Arabic Dialect included Marico, Aljazeera, Mauritania, Tunisia, and Libya. Every dialect has various sounds.

Sound /q/ is pronounced /'/ in EGY Dialect but it is pronounced /g/ in GLF and IRQ. This changing sound is phenomenon in Arabic Dialect. In line with this, dialect study is needed in order to research many kinds of dialect sounds. Chamber and Trudgill (2004:3) stated that Dialect Study is a branch of Linguistic which is studied dialects. Muslich (2012:3) explained that the study of dialect used Phonology Theory to analyze dialect sound variation. The study of phonology is able to research Arabic Dialects based on the sound variation, charateristic and also its changing.

Nowadays, most of Hadramaut societies are spread until Indonesia. Pasar Kliwon Surakarta is one of city where Hadramaut lives . In the beginning, they came to Surakarta to preach and trade. Then, the men of Hadramaut got married with Pasar Kliwon women. Because of that marriage they communicate and consort with indigene societies. There, they talk using Hadramiyah dialect which different from fushcha> and they also used Bahasa.

The research observation held on 10 - 20 February 2014, the researcher got a conclusion that Pasar Kliwon Arabian are able to talk using Arabic Dialect. Commonly, they talk fushcha> language when preaching in the mosque or transaction sale in front of the shop or market. The preaching is held before praying Dhuhur in Riyadh mosque and after praying subuh in As segaf mosque every day. Look at the dialog which was found bellow:

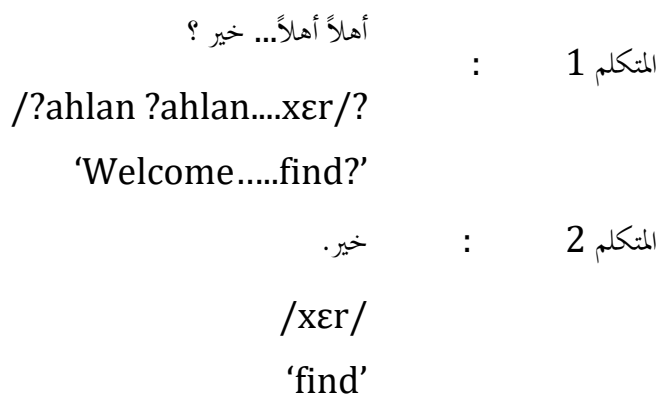

In the reality, original sound of /xer/ is /xayr/ which is from fushcha>. Look at the conversation above! It contains the changing sound /xayr/ becomes /xer/. There is a diphthong /ay/ in the sound /xayr/, whereas there is vowel /e/in the /xer/. Substantively, vowel /a/ in the diphthong /ay/ is low sound, whereas the sound /y/ in that diphthong is high sound. Vowel /y/ is formed from YA which harakat sukun and previous letter are harakat fathah, as a result the speaker feels difficulty to pronounce it. However, Vowel /e/ in /xer/ makes the speaker pronounce it easily.

In the observation of this research, the researcher also found this statement bellow:

$$
\text { المحاصر أنّ رسول الله صلى الله عليه وسلم يغول .... }
$$

/?anna rasu:lullah șhallallahu 'alayhi wa sallam yagu:l...../

'The Prophet Muhammad said......'

The statement above was spoken by one of the preacher in Riyadh Mosque. The word / yaqu:l/ is fushcha> but pronounced / yagu:l/. There is changing sound /q/ becomes /g/. The sound /q/ is uvular whereas sound /g/ is velar. This changing is a 
phenomenon of Arabic Dialect in Pasar Kliwon Surakarta. Actually, the variations of Arabic Dialect in Pasar Kliwon are very various as a result phonological research is needed.

\section{THEORY AND METHODS}

Sholihatin (2008) has researched sound variation of Pekalongan society. Her research result stated that the variation depends on speaker relation background with the listener and also the topic of the speech. Mulia (2009) has also researched about sound variation in her thesis 'Sound Variation Qira'ah As sab'ah". Her research result stated that Qira'ah As Sab'ah happened because of dialect changing. Sholihah (2009) has also researched about Haul Al Habib Ali Al Habsyi tradition in Pasar Kliwon Surakarta based on culture analysis. All the research have not studied about Arabic Dialect specifically yet. In the return of this, this research focus on the study of Pasar Kliwon Arabic Dialect which is based on 100 Swadesh vocabularies. This research studies the variation and the changing sound of that dialect.

Pasar Kliwon Surakarta was choosen as the place of this research because of some reason. First is Arabian who live in Pasar Kliwon are able to pronounce and talk with Arabic Dialect. Second, this research aims to know variation of dialect specifically. The last, Pasar Kliwon is a centre of Arabian in Surakarta.

According to background above, this research studied variation of dialect specifically in Pasar Kliwon. This research also explained many kinds of dialec variation and its changing. The analysis used Arabic Phonological theory including sound Pronunciations, characteristics, formed and changing. Ramadhan (1997:42-61) explained that there are 10 pronunciations in Arabic such as billabial, labio dental, dental, dental alveolar, alveolar, palatal, velar, uvular, pharyngeal, and laryngeal. Hasan (1990:86) also explained the ccharacteristic of Arabic divided by four such as plossive, fricative, affricative, and liquids. Anis (1999: 26 - 41) mentioned that vowel, consonant and semi vowel sound. Crowley (1987:25-47) and Muslich (2012:118-127) also explained more about sound changing theory.

The data was collected on April 20- 2014 by using Simak and Cakap method. Sudaryanto (1993:137) explained that while the researcher applying cakap method, the researcher gained the information by talking and communicating with the informant directly. Here, the researcher talked and asked for question to the Arabian which lives in Pasar Kliwon directly and all the questions based on the 120 vocabularies of Swadesh. The applied research technique was note and record. Sudaryanto (1993: 135) explained that the researcher gained the information using recorder. After collecting the data, the researcher classified in to data card which is suitable with the sound variations and its changing. Then the data are analyzed by padan method based on informant voice, Arabian in Pasar Kliwon.

\section{RESULT AND DISCUSSION}

\section{Sound Variation of Arabic Dialect Pasar Kliwon}

There are four sound variations of Arabic Dialect found in Pasar Kliwon. First, the vowel sound is harakat (/a/, /i/, /u/, /e/, /ə/, /ع/, /o/) and mad (/a:/, /i:/, /u:/). Second, diphthongs is /aw/ and /ay/. Third, consonant is plosive, fricative, affricative, voiced, voiceless, and velarization.

a. Vowel Sound

Vowel sound is found in two kind, short vowel and long vowel. The short vowel is harakat (/a/, /i/, /u/, /e/, /ə/, /ع/, /o/) and the long mad (/a:/, /i:/, /u:/). Holes 
(1995:59) explained that Arabic dialect contained syllable. Syllable is divided by two kinds, opened syllable (Cv, Cv:) and closed syllable (CvC, $\mathrm{Cv}: \mathrm{C}, \mathrm{CvCC}, \mathrm{Cv}: \mathrm{CC})$.

1) Vowel $(/ \mathrm{a} /)$

Vowel $(/ \mathrm{a} /)$ is found in five kinds. First, vowel (/a/) appeared in the first

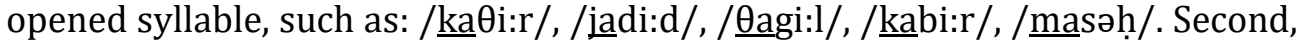
vowel (/a/) appeared in the second opened syllable, such as: /kayfa/. Third, vowel $(/ \mathrm{a} /)$ appeared in the first opened syllable and the second closed syllable, such as: /wa lad/ and / ja bal/. Fourth, vowel (/a/) appeared in the first closed syllable, second opened syllable, and third closed syllable, such as: /?ar ba 'ah/. Fifth, vowel (/a/) appeared in the first opened syllable and third closed syllable, such as: / kalimah/. In that pronouncing, the tongue down and avoided from the hard palate. Then, the lips don't shape the circle.

2) Vowel $(/ \mathrm{i} /)$

Vowel (/i/) is found in two kind. First, vowel (/i/) appeared in the first opened syllable, such as: /rijel/, /li ?anna/, /rija:l/, /hina:/. Second, vowel (/i/) appeared in the second opened syllable, such as: /fa:kihah/ and /kalimah/. In that pronouncing, the tongue up and lower jaw approached the canopy. Then, the lips don't shape the circle.

3) Vowel $(/ \mathrm{u} /)$

Vowel $(/ \mathrm{u} /)$ is found in two kind. First, vowel $(/ \mathrm{u} /)$ appeared in the first opened syllable, such as: /buhairah/ dan /huna:/. Second, vowel (/u/) appeared in the second opened syllable, such as: /?abuya:/ dan /nahnu/. In that pronouncing, the tongue up and lower jaw approached the canopy. Then, the lips shape the circle.

4) Vowel $(/ \mathrm{e} /)$

Vowel (/e/) is found in two kind. First, vowel (/e/) appeared in the first opened syllable, such as: / $\mathrm{kef} /$. Second, vowel (/e/) appeared in the second opened syllable, such as: /fi?en/. In that pronouncing, the ahead of tongue up and approach the canopy. Then, the lips don't shape the circle.

5) Vowel (/ə/)

Vowel (/ə/) is found in two kind. First, vowel (/ə/) appeared in the first

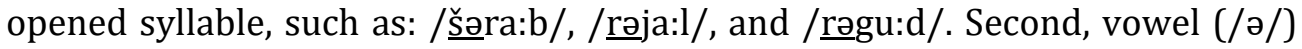
appeared in the second opened syllable, such as: /lahəm/, /kaləb/, /galəab/, /wasəx/, and /nahən/. The /kaləb/ utterance included vowel /ə/ between two consonant sound sukun. The vowel /ə/ is between sukun consonant /l/ and $/ \mathrm{b} /$. In the pronouncing /ə/, the tongue is in the middle of mouth and the lips don't shape the circle.

6) Vowel $(/ \varepsilon /)$

Vowel $(/ \varepsilon /)$ is found in three kinds. First, vowel $(/ \varepsilon /)$ appeared in the first opened syllable, such as: $/ \underline{\mathrm{l}} \underline{\mathrm{g}}^{\prime} \mathrm{eb} /$. Second, vowel $(/ \varepsilon /)$ appeared in the second closed syllable, such as: / $\underline{\underline{x} r} /$. Third, vowel $(/ \varepsilon /)$ appeared in the first opened syllable and the second closed syllable, such as: /šsbch/. Fourth, vowel $(/ \varepsilon /)$ appeared in the second closed syllable, such as: /?iӨnen/. In that pronouncing, the ahead of tongue up and approach to the hard palate. Then, the lips don't shape the circle.

7) Vowel $(/ \mathrm{o} /)$

Vowel $(/ \mathrm{o} /)$ is found in two kinds. First, vowel $(/ \mathrm{o} /)$ appeared in the first opened syllable, such as: /moya/. Second, vowel (/o/) appeared in the first closed syllable /zoj/, and / $\mathrm{mot} /$. In that pronouncing, the ahead of tongue up and approach the canopy. Then, the lips shape the circle. 
Whereas long vowel or "mudud" is found in three kinds. Firstly, long vowel /a:/ which is placed in the first opened syllable, such as /ja:lis/, /ha:ða/, and /wa:hid/. Long vowel /a/ is also found in the second opened syllable, /hina:/ and //saha:b/. Vowel /a/ is also found in the third closed syllable /hayawa:n/. Secondly, long vowel /i:/ is found in the first closed syllable /ri:h/ and second closed syllable, /Oagi:l/, /gari:b/, /yami:n/, /țawi:l/, /gali:l/, and /sami:n/. Thirdly, long vowel $/ \mathrm{u} /$ is found in the second closed syllable /mablu:l/ and /ḍuru:s/.

b. Diphthong

In the Arabic dialect Pasar Kliwon included diphthong sound is divided by two kinds, /ay/ and /aw/. The diphthong sound /ay/ appeared in the first closed syllable, such as /țayr/, and /zayn/. The diphthong sound /ay/ also appeared in the first opened syllable, such as: /kayfa/. The diphthong sound /aw/ appeared in the first opened syllable, such as: /?awla:d/ and /zawjah/.

c. Consonant

Consonant sound in the Pasar Kliwon Arabic Dialect included 27 sounds ( م ؛ Whereas based on the way of sound pattern, consonant sound is found 4 kinds : plosive, fricative, affricative, and liquid. Based on sound track tremble, consonant sound is found two kinds: voiced and voiceless, and based on tongue movement is found a valorization.

Plosive sounds included (ب، د، ط، ض، ت، s، ك) Example when pronounce ب/b/in the second syllable in the word /?abuya/, the lips meet and close perfectly as a result the air flows from the lung is completely resisted. Then, two lips is suddenly

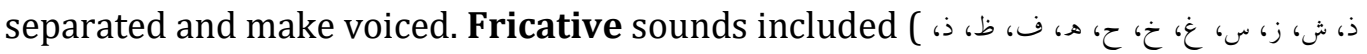
ث). Example when pronouncing $\dot{s} / ð /$ in the word / ha:ða/, the air completely flows from the lung without obstacle and the air duct just tighten, so the air fiddle the tip of tongue and tip of the tooth. The air which is fiddled articulation point makes a sound of hissing. Affricative sound appeared when pronouncing $\mathrm{r} / \mathrm{j} /$ in the word /ja:?/. The air flows from the lung completely endured in the hard palate, and then the tongue is slowly separated from hard palate and fiddled articulation point.

Liquid sound appeared in the sound of (ر) ل، م، ن، ع ( ) Example, when pronouncing $/ \mathrm{m} /$ in the word /man/. The air flows across the nose when the air is hindered in the two lips articulation point.

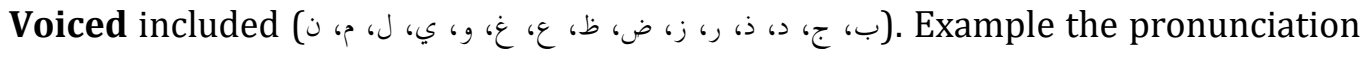
of $\dot{\varepsilon} / \dot{\mathrm{g}} /$ in the word /gamar/. The air flows from the red lane and fiddles articulation point in the hard palate as a result hissing sound is created. Sound

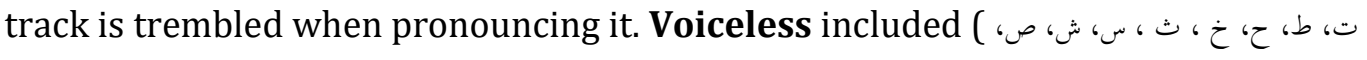
(ه، ك، ف (ه) For example the pronunciation of in the word /fawa:kih/, the air flows from the lung and fiddles the bottom lips and top tooth without creating sound track trembling. 
Velarization sound included sound (ص ، غ ض، خ، ظ، ط) Example when pronouncing $b / t$ \}/ in the word /tayr/, the back part of the tongue rises up and closes to hard palate and then when the upper end of the tongue meeting with the ahead of hard palate. For the other example is when pronouncing ص/s/ in the word /sahi:h/, the position of tongue is like س/s/. However, when pronouncing ص ص/ș/, the tongue shape concave in mouth. The tip and base of tongue approach the hard palate.

d. Semi-Vowel

The Semi-vowel sound is found in Arabic dialect Pasar Kliwon included /y/ and /w/. The semi-vowel / $\mathrm{y} /$ appeared in the first opened syllable of the word /walad/. In that pronouncing /w/, the position of tongue be the same with pronouncing the vowel $/ \mathrm{u} /$. However, hole in the mouth when the pronouncing /w/ is smaller than the pronouncing of the vowel /u/. So, sound of /w/ similar with the vowel sound. And then, when the pronouncing /w/, the air fiddle the artculation point which tighten and makes sound of hissing. That sound of hissing caused the sound /w/ like consonant sound. Therefore, sound /w/ is called semivowel. The pronouncing of semi-vowel /y/ is be same with pronouncing vowel /i/.

\section{Sound Changing}

After variation analysing of Arabic dialect Pasar Kliwon, the researcher investigated the sound change in that dialect. The sound change analysing used the sound alteration theory according to Crowley (1992) and Muslich (2012). The sound change included vowel, consonant, and diphthong sound.

a. The vowel change

The vowel sound change is found in that dialect is lenition, anaptycsis, apocope, and metathesis. First, lenition is sound change from loud sound to weak sound. The lenition change is found in that dialect is sound change $/ \mathrm{i} / \mathrm{H} / \mathrm{o} /$. Example, sound change of word /miya:h/ $\rightarrow$ /moya/. That sound change of /i/ $\rightarrow$ /o/ to expedite the speaker in pronounciation. Second, anaptycsis is additional vowel sound in the certain word. The anaptycsis change is found in that dialect is sound additional /ə/. Example, additional sound of word /ward/ $\rightarrow$ /warəd/. Third, apocope is sound ellipsis in the end word. The apocope change is found in that dialect is sound ellipsis /a/. Example, sound ellipsis of word /fəza'a/ $\rightarrow /$ fəza'/ and /ja:?a/ $\rightarrow /$ ja:?/. Fourth, metathesis is sound sequence change in certain word. The metathesis change is found in that dialect is sequence change sound /i/. Example, sound sequence change /i/ in the word /kalimah/ $\rightarrow$ /kilmah/.

b. The consonant change

The consonant sound change is found in that dialect is lenition, anaptycsis, apocope, and sincope . First, lenition change is found in that dialect is sound change $/ \mathrm{q} / \rightarrow / \dot{\mathrm{g}} /$. Example, sound change of word $/$ qamar $/ \rightarrow /$ gamar $/$,

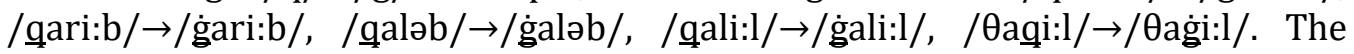
sound of /q/ is uvular sound but sound of $/ \dot{\mathrm{g}} /$ is velar sound. Second, anaptycsis change is found in that dialect is sound additional /ð/. Example, additional sound of word /ha:?ula:?/ $\rightarrow$ /ha: $\underline{\text { an}}$ ?ula:?/. Third, apocope change is found in that dialect is sound ellipsis /w/. Example, sound ellipsis of word /huwa/ $\rightarrow /$ hu/. Fourth, sincope is sound erasing in certain word. The sincope change is found in that dialect is sound erasing /?/. Example, erasing sound /?/ in the word /ra?s/ $\rightarrow$ /ras/. 
c. The diphthong change

The diphthong sound change is found in that dialect is monophthongization. Monophthongization is diphthong sound change into vowel sound. Example: diphthong sound change is found in sound change $/ a y / \rightarrow / \varepsilon /$ of

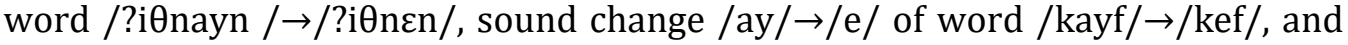
sound change /aw $/ \rightarrow / \mathrm{o} /$ of word $/ \mathrm{mawt} / \rightarrow / \mathrm{mot} /$.

\section{CONCLUSION}

Based on this research result can be concluded in six conclusions. First, the vowel sound in Arabic dialect Pasar Kliwon divided by two kinds: short vowel sound (/a/, /i/, $/ \mathrm{u} /, / \mathrm{e} /, / \partial /, / \varepsilon /, / \mathrm{o} /)$ and long vowel sound (/a:/, /i:/ /u:/). Second, there are twenty seven consonant sounds. Based on sound producing are divided by four kinds: plosive

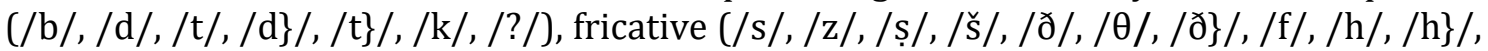
$/ \mathrm{x} /, / \dot{\mathrm{g}} /)$, affricative $(/ \mathrm{j} /)$, liquid $(/ \mathrm{r} /, / \mathrm{l} /, / \mathrm{m} /, / \mathrm{n} /, / \mathrm{w} /, / \mathrm{y} /, / \mathrm{l} /)$ and based on sound vibration are divided by two, voiced $(/ \mathrm{b} /, / \mathrm{j} /, / \mathrm{d} /, / \mathrm{\partial} /, / \mathrm{r} /, / \mathrm{z} /, / \mathrm{d}\} /, / ð\} /, / \mathrm{l}, / \mathrm{g} /, \mathrm{l} / \mathrm{w} /$, $/ \mathrm{y} /, / \mathrm{l} /, / \mathrm{m} /, / \mathrm{n} /)$ and voiceless $(/ \mathrm{t} /, / \theta /, / \mathrm{h} /, / \mathrm{x} /, / \mathrm{s} /, / \mathrm{s} /, / \mathrm{s}\} /, / \mathrm{t}\} /, / \mathrm{f} /, / \mathrm{k} /, / \mathrm{h} /)$, and based on speech organ act is velariation sound $(/ \mathrm{s}\} /, / \mathrm{g} /, / \mathrm{d}\} /, / \mathrm{x} /, / \partial\} /, / \mathrm{t}\} /)$. Third, the sound variation of semi-vowel is $/ \mathrm{w} /$ and $/ \mathrm{y} /$. Fourth, the vowel sound change divided by four kinds: lenition ( /i/ $\rightarrow$ /o/, /u/ $\rightarrow$ /i/, /a/ $\rightarrow$ /ə/), anaptycsis (/ə/), apocope (/a/), metathesis $(/ \mathrm{i} /)$. Fifth, the consonant sound change divided by four kinds: lenition $(/ \mathrm{q} / \rightarrow / \mathrm{g} /$ ), anaptycsis (/ð/), apocope (consonant /w/), and sincope (/?/). Sixth, diftong sound cange is monoftongitation ( /ay/ $\rightarrow$ /e/, /ay/ $\rightarrow / \varepsilon /$, /aw/ $\rightarrow /$ o/, /ay/ $\rightarrow / \varepsilon /$ ).

\section{DAFTAR PUSTAKA}

Ayatrohaedi. (2002). Pedoman penelitian dialektologi. Jakarta: Pusat Bahasa Departemen Pendidikan Nasional.

Biadsy, F, et all. (tt). Spoken Arabic dialect identification using phonotactic modeling. New York: Colombia University.

Berg, V. D. (1989). Hadramaut dan koloni Arab di Nusantara. Jakarta: INIS

Chambers \& Trudgill, P. (2004). Dialectology second edition. New York: Cambridge University Press.

Crowley, T. (1992). An introduction to historical linguistic. New York: Oxford University Press.

Hadi, S.et al. (2003). "Perubahan fonologis kata-kata serapan dari bahasa Arab dalam bahasa Indonesia". Jurnal Humaniora Volume XV. Yogyakarta: Fakultas Ilmu Budaya Universitas Gajah Mada.

Handani, M. (2009). Analisis fonologis Qira:?atu al-sab'ati. Skripsi. Depok: Fakultas Ilmu Budaya Program Studi Arab Universitas Indonesia.

Holes, C. (1995). Modern Arabic structures, function, and varieties. New York: Longman Publishing. 
Al-Khuli, M.A. (1982). A Dictionary of theoritical linguistics. Libanon: Libanon Pustaka.

Kridalaksana, H. (2005). Mongin Ferdinand De Saussure (1857-1913) Peletak dasar strukturalisme dan linguistik modern. Jakarta: Yayasan Obor Indonesia.

Kridalaksana, H. (1993). Kamus linguistik edisi III. Jakarta: Gramedia.

Mahsun. (2010). Geneolinguistik kolaborasi linguistik dengan Genetika dalam pengelompokan bahasa dan populasi penuturnya. Yogyakarta: Penerbit Pustaka Pelajar.

Mahsun. (2005). Metode penelitian bahasa. Jakarta: Rajawali Press.

Mahsun. (1995). Dialektologi diakronis sebuah pengantar. Yogyakarta: Gajah Mada University Press.

Muhammad. (2012). Metode dan teknis analisis data linguistik. Yogyakarta: Liebe Book Press.

Muslich, M. (2012). Fonologi bahasa Indonesia tinjauan diskriptif sistem bunyi bahasa Indonesia. Jakarta: Bumi Aksara

Sari, M.N. (2009). "Perubahan fonologis dan semantis istilah hukum bahasa Indonesia yang berasal dari bahasa Belanda". Skripsi. Depok: Fakultas Ilmu Budaya Program Studi Belanda Universitas Indonesia.

Rahmawati, I. (2007). "Perubahan fonologis dan perubahan makna pada kata serapan bahasa Indonesia dalam bahasa Belanda". Skripsi. Depok: Fakultas Ilmu Budaya Program Studi Belanda Universitas Indonesia.

Shalihatin, A. (2008). "Pemilihan kode pada masyarakat keturunan Arab di Noyontaan, kota Pekalongan: kajian sosiolinguistik". Tesis S-2. Semarang: Program Pascasarjana Universitas Diponegoro.

Sholihah, N. (2009). "Tradisi Haul Habib Ali Al Habsyi Masyarakat Muslim Muhibbin di Pasar Kliwon Surakarta Tahun 1980-2006". Skripsi. Surakarta: Fakultas Sastra dan Seni Rupa Universitas Sebelas Maret Surakarta.

Sudaryanto. (1993). Metode dan aneka teknik analisis bahasa, pengantar penelitian wahana kebudayaan secara linguistis. Yogyakarta: Duta Wacana University Press. 